\title{
Mingulay reef complex: an interdisciplinary study of cold-water coral habitat, hydrography and biodiversity
}

\author{
J. M. Roberts ${ }^{1,2,9, *}$, A. J. Davies ${ }^{1,10}$, L. A. Henry ${ }^{1}$, L. A. $\operatorname{Dodds}^{1}$, G. C. A. Duineveld ${ }^{3}$, \\ M. S. S. Lavaleye ${ }^{3}$, C. Maier ${ }^{3,4}$, R. W. M. van Soest ${ }^{5}$, M. J. N. Bergman ${ }^{3}$, \\ V. Hühnerbach ${ }^{6}$, V. A. I. Huvenne ${ }^{6}$, D. J. Sinclair ${ }^{1}$, T. Watmough ${ }^{1,7}$, D. Long ${ }^{8}$, \\ S. L. Green ${ }^{6,8}$, H. van Haren ${ }^{3}$ \\ ${ }^{1}$ Scottish Association for Marine Science, Dunstaffnage Marine Laboratory, Oban, Argyll PA37 1QA, UK \\ ${ }^{2}$ Center for Marine Science, University of North Carolina, Wilmington, 5600 Marvin K. Moss Lane, Wilmington, \\ North Carolina 28409, USA \\ ${ }^{3}$ Royal Netherlands Institute for Sea Research, PO Box 59, 1790 AB Den Burg, Texel, The Netherlands \\ ${ }^{4}$ CNRS, Laboratoire d'Océanographie de Villefranche, 06230 Villefranche-sur-Mer, France \\ ${ }^{5}$ Zoological Museum of the University of Amsterdam, PO Box 94766, 1090GT Amsterdam, The Netherlands \\ ${ }^{6}$ National Oceanography Centre, University of Southampton, Waterfront Campus, European Way, Southampton SO14 3ZH, UK \\ ${ }^{7}$ School of Life Sciences, Heriot-Watt University, Edinburgh EH14 4AS, UK \\ ${ }^{8}$ British Geological Survey, Murchison House, West Mains Road, Edinburgh EH9 3LA, UK \\ ${ }^{9}$ Present address: Centre for Marine Biodiversity \& Biotechnology, School of Life Sciences, Heriot-Watt University, \\ Edinburgh EH14 4AS, UK \\ ${ }^{10}$ Present address: School of Ocean Sciences, Bangor University, Menai Bridge LL59 5AB, UK
}

\begin{abstract}
The Mingulay reef complex in the Sea of the Hebrides west of Scotland was first mapped in 2003 with a further survey in 2006 revealing previously unknown live coral reef areas at 120 to $190 \mathrm{~m}$ depth. Habitat mapping confirmed that distinctive mounded bathymetry was formed by reefs of Lophelia pertusa with surficial coral debris dating to almost $4000 \mathrm{yr}$. Benthic lander and mooring deployments revealed 2 dominant food supply mechanisms to the reefs: a regular rapid downwelling of surface water delivering pulses of warm fluorescent water, and periodic advection of high turbidity bottom waters. Closed chamber respirometry studies suggest that L. pertusa responds to seawater warming, such as that seen during the rapid downwelling events, with increases in metabolic rate. Lipid biomarker analysis implies that corals at Mingulay feed predominantly on herbivorous calanoid copepods. Integrating geophysical and hydrographical survey data allowed us to quantify the roles of these environmental factors in controlling biodiversity of attached epifaunal species across the reefs. Longitudinal structuring of these communities is striking: species richness $(\alpha)$ and turnover $(\beta)$ change significantly west to east, with variation in community composition largely explained by bathymetric variables that are spatially structured on the reef complex. Vibro-cores through the reef mounds show abundant coral debris with significant hiatuses. High resolution side-scan sonar revealed trawl marks in areas south of the coral reefs where vessel monitoring system data showed the highest density of local fishing activity. The interdisciplinary approach in this study allowed us to record the food supply and hydrographic environment experienced by L. pertusa and determine how it may be ecophysiologically adapted to these conditions. Improved basic understanding of cold-water coral biology and biodiversity alongside efforts to map and date these long-lived habitats are vital to development of future conservation policies.
\end{abstract}

KEY WORDS: Ecological engineer $\cdot$ Lophelia pertusa $\cdot$ Seamounts $\cdot$ Internal waves 


\section{INTRODUCTION}

Corals are not restricted to tropical latitudes and shallow water depths; indeed, $66 \%$ of coral species are found at depths more than $50 \mathrm{~m}$ (Cairns 2007). Of these corals, 17 scleractinian species produce skeletal frameworks but only 6 (Enallopsammia profunda, Goniocorella dumosa, Lophelia pertusa, Madrepora oculata, Oculina varicosa and Solenosmilia variabilis) are currently known to form significant deep, coldwater coral reef habitat (Roberts et al. 2006, 2009).

Although records of the most widespread reef framework-forming cold-water coral, Lophelia pertusa, go back to the mid-18th century (Pontoppidan 1755, Gunnerus 1768), our ability to map and characterise the reef habitats it forms has advanced dramatically over the last decade, driven by technical advances and exploratory continental shelf mapping by the hydrocarbon industry. Techniques of marine habitat mapping based on wide area bathymetric and backscatter data from multibeam echosounders combined with higher resolution side-scan sonar and visual groundtruthing have now revealed the ubiquity of both coldwater coral reefs and larger coral carbonate mounds, notably in the Atlantic Ocean.

Many of the earliest reports of cold-water coral reefs noted their association with locally increased water flow thought to both increase food supply and limit sediment smothering. More recent work has shown that particular interactions between water currents, internal waves and seabed topography may locally enhance food supply to these sessile, benthic suspension-feeders (Frederiksen et al. 1992, White et al. 2005, Thiem et al. 2006). However, the origin of this food has been the subject of lively debate. Proponents of the 'hydraulic theory' postulate a role for a local hydrocarbon seep-based food supply (e.g. Hovland \& Thomsen 1997, Henriet et al. 1998, Hovland \& Risk 2003, Hovland 2008), while others point to the weight of evidence for dependence on surface primary production (e.g. Duineveld et al. 2004, Kiriakoulakis et al. 2007).

These highly complex 3-dimensional cold-water coral habitats have long been known to support many other species, particularly suspension-feeding invertebrates such as other corals, sponges, anemones, hydroids, bryozoans and ophiuroids. Cold-water coral habitats are typically richer in species (alpha diversity, $\alpha$ ) than neighbouring habitats (Henry \& Roberts 2007), with the variety of seabed habitat types promoting elevated beta (or species turnover, $\beta$ ) diversity (Roberts et al. 2008). Regional compilations of species found with Lophelia pertusa currently indicate over 1300 species in the northeast Atlantic (high gamma diversity, $\gamma$ ). Within the coral habitat itself, both $\alpha$ and $\beta$ diversity vary across gradients of depth and the amount of live coral (Jonsson et al. 2004,
Mortensen \& Fosså 2006, van Soest et al. 2007, Cordes et al. 2008). Thus, the role of species like $L$. pertusa as significant agents of ecological engineering on continental shelf, slope and seamount settings is becoming increasingly more evident. Yet the mechanisms driving biodiversity in these habitats still remain largely unexplored and unquantified, especially with respect to hydrographic, bathymetric and geographic factors that almost certainly affect biodiversity in these habitats.

In parallel with the last decade's discoveries of coldwater coral habitats and their biodiversity, a rich vein of studies have examined the longevity of both the individual corals and the structures they form. Individual antipatharian corals may live for 100s or even 1000s of years (Roark et al. 2006), and the remains of cold-water scleractinians can persist for 10 s to 100000 s of years. Thus, in addition to functioning as ecosystem engineers over time scales that far exceed their individual life spans, cold-water corals are unique long-term environmental archives of, among other parameters, seawater temperature (Smith et al. 2000, Rüggeberg et al. 2008) and ocean ventilation history (Adkins et al. 1998, Mangini et al. 1998). However, interpreting these records is greatly complicated by 'vital effects' of coral calcification (Weber \& Woodhead 1972), and it is clear that a better understanding of coral feeding, physiology and growth will help interpret these important climatic archives (Roberts et al. 2009).

The present study describes a cold-water coral reef habitat to the west of Scotland. The Mingulay reef complex was first mapped in 2003 (Roberts et al. 2005) and since then has become the focus of a series of interdisciplinary studies examining (1) the reef and surrounding habitats, (2) hydrography and food supply, (3) coral ecophysiology, (4) spatial patterns in biodiversity and (5) the temporal history of reef development. We examine each issue in turn and present new data on extent of reef occurrence, local morphology of coral colonies, internal structure of the reefs and species found in the Mingulay area. We conclude by synthesising the findings and briefly reviewing the benefits of integrated, interdisciplinary research to develop future coherent policies for the long-term conservation of cold-water coral reefs.

\section{HABITAT MAPPING AND ANTHROPOGENIC IMPACTS}

There are relatively few records of Lophelia pertusa from the inshore shelf waters of the west coast of Scotland. Fleming (1846, p. 82) presented the first British record of Madrepora prolifera (=L. pertusa) to the Royal Society of Edinburgh, noting that it '...was found last summer by fishermen, their lines having become en- 


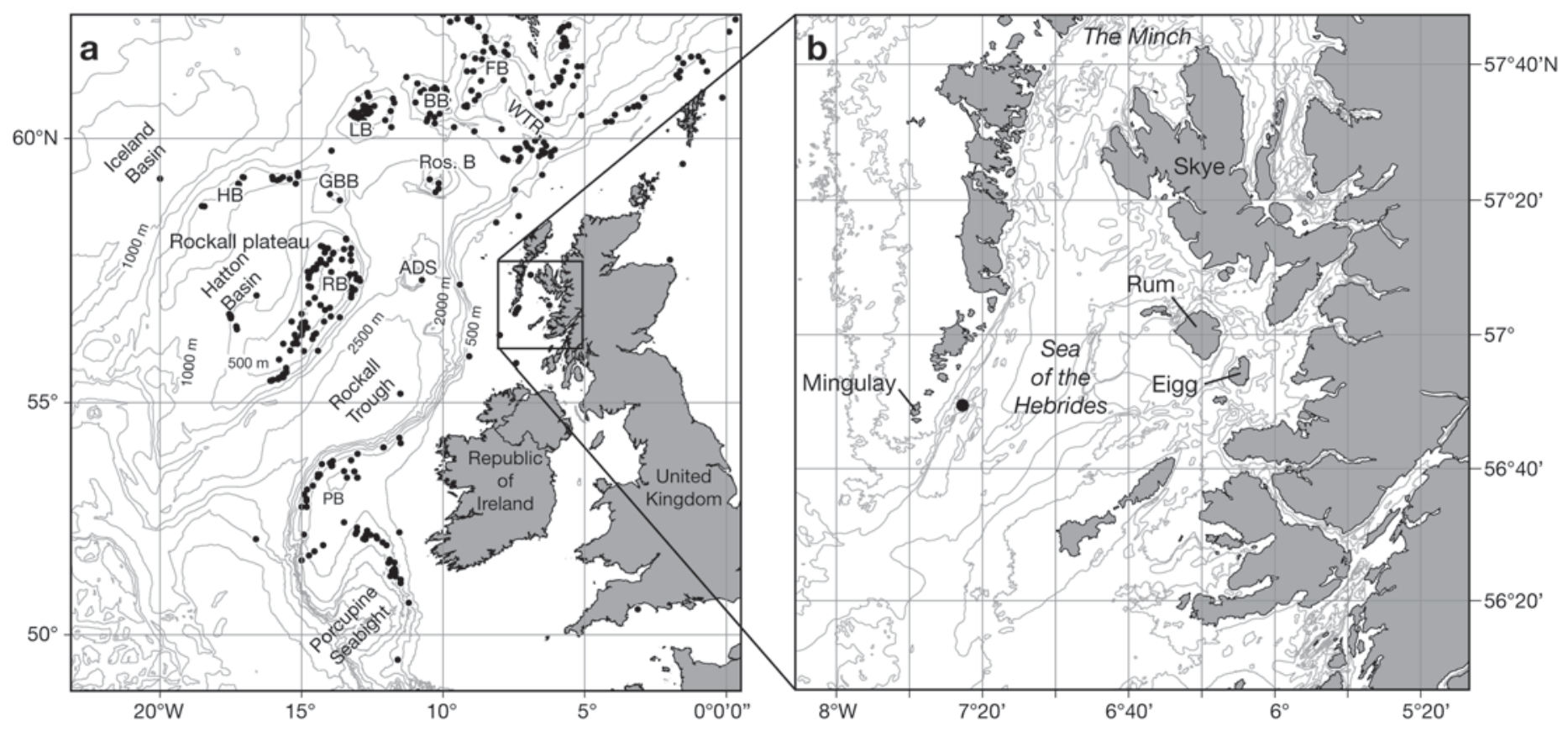

Fig. 1. (a) Locations of Lophelia pertusa to the west of the UK. ADS: Anton Dohrn Seamount; BB: Bill Bailey's Bank; FB: Faroe Bank; GBB: George Bligh Bank; HB: Hatton Bank; LB: Lousy Bank; PB: Porcupine Bank; RB: Rockall Bank; Ros. B: Rosemary Bank; WTR: Wyville Thomson Ridge. (b) Location of the Mingulay reef complex (•) and other areas west of Skye and between Rum and Eigg where L. pertusa has been recorded. Contours given at $100 \mathrm{~m}$ intervals

tangled with it, in the sea between the islands of Rum and Eigg'. The first record of L. pertusa from the area east of the island of Mingulay (Fig. 1) was also from a coral colony collected by a fisher in the early 1900s and subsequently transferred to the Hunterian Zoology Museum (University of Glasgow). No further records were made until 1968 when coral material was sampled during a research cruise aboard the RV 'John Murray' and subsequently in 1970 when the 'Pisces II' manned submersible photographed small individual colonies during a study of local seafloor geology (Eden et al. 1971). However, it was not until 2001 that the Mingulay area was again examined, this time using a $3.5 \mathrm{kHz}$ subbottom profiler to reveal reef-like topography, and limited bottom sampling that recovered $L$. pertusa coral rubble and small fragments of live coral (Griffiths 2002).

The growing evidence for coral occurrence east of Mingulay led to a multi-partner project to survey the area using a multibeam echosounder (MBES) in 2003 (Roberts et al. 2004, 2005). This survey used existing bathymetric information to guide a series of short MBES surveys. Although surveys were carried out in all areas with historical records of Lophelia pertusa, reef mounds were only found in 3 of 5 sites mapped $14 \mathrm{~km}$ east of Mingulay in the Sea of the Hebrides. The surveys used a $200 \mathrm{kHz}$ Kongsberg EM2000 MBES with approximately $50 \%$ overlap between survey lines. Mounded seafloor bathymetry was verified as reefs of $L$. pertusa using seabed video surveys. Subse- quent acoustic surveys in 2006 from the RV 'Pelagia' (Maier 2006) used the lower resolution 30 kHz Kongsberg EM300 MBES to extend this initial survey to a total area of approximately $100 \mathrm{~km}^{2}$. The 2006 survey revealed 2 previously unknown reef areas, an elongate reef nicknamed 'Banana Reef' and a series of mounds called 'Four Mounds' (Fig. 2a).

The bedrock underlying the Mingulay reef complex is made up of Mesozoic sediments and Palaeogene intrusives infilling a graben between the Outer Hebrides and mainland Scotland formed in Precambrian gneiss. These rocks have been glacially eroded by ice sheets moving south within the Minch, the more resistant intrusives creating upstanding features. The resulting seabed landscape forms a complex topography of hollows reaching depths $>250 \mathrm{~m}$ and rock ridges that may be several kilometres across and extend $>100 \mathrm{~m}$ above the surrounding seafloor. For example, Mingulay Area 1 (Fig. 2a) is believed to be a northward dipping dolorite sill intruded within Lower Jurassic sedimentary mudstone rocks (Stewart \& Gatliff 2008). This forms an asymmetric east-west seabed ridge with a steep southern slope and a more gentle slope to the north. Coral mounds are most developed on the gentler northern slope, where their occurrence seems strongly related to the distinctive local hydrography, (see section 'Hydrography and food supply' below). In contrast, the thin, laterally extended morphology of Banana Reef is more compatible with an igneous dyke 

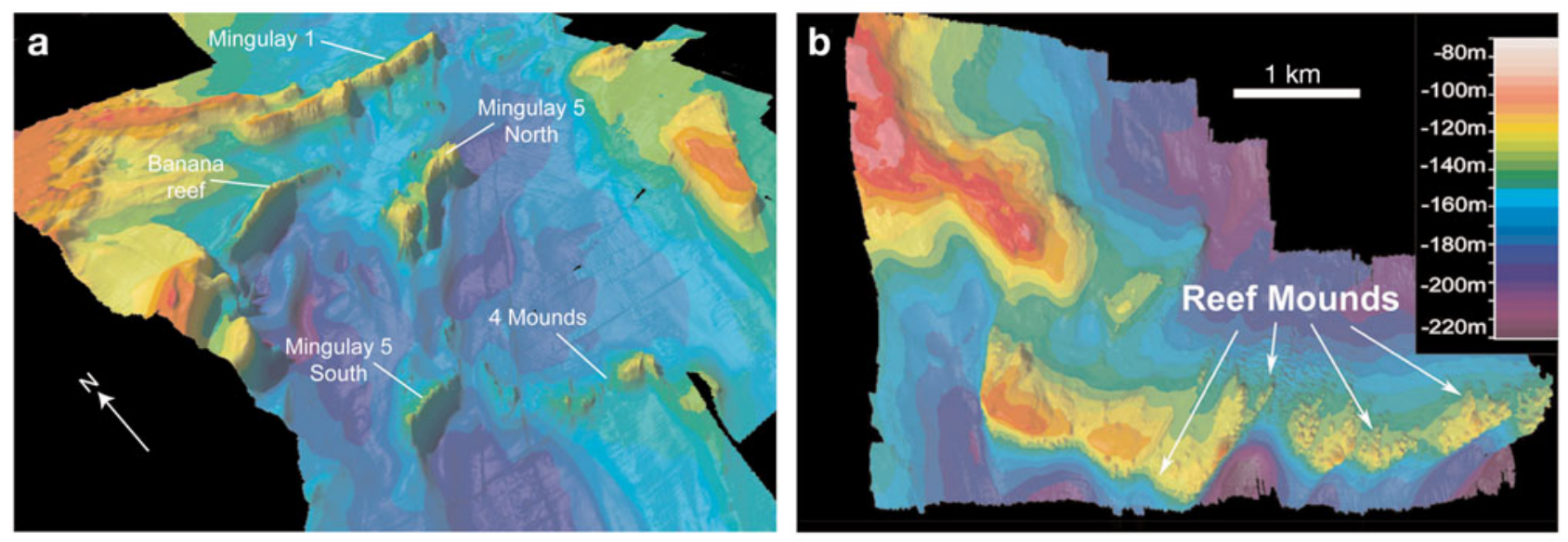

c

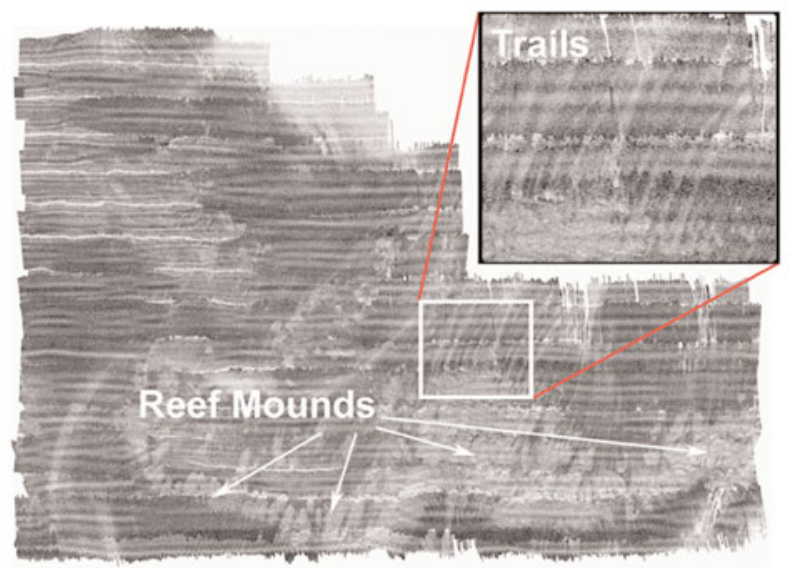

d

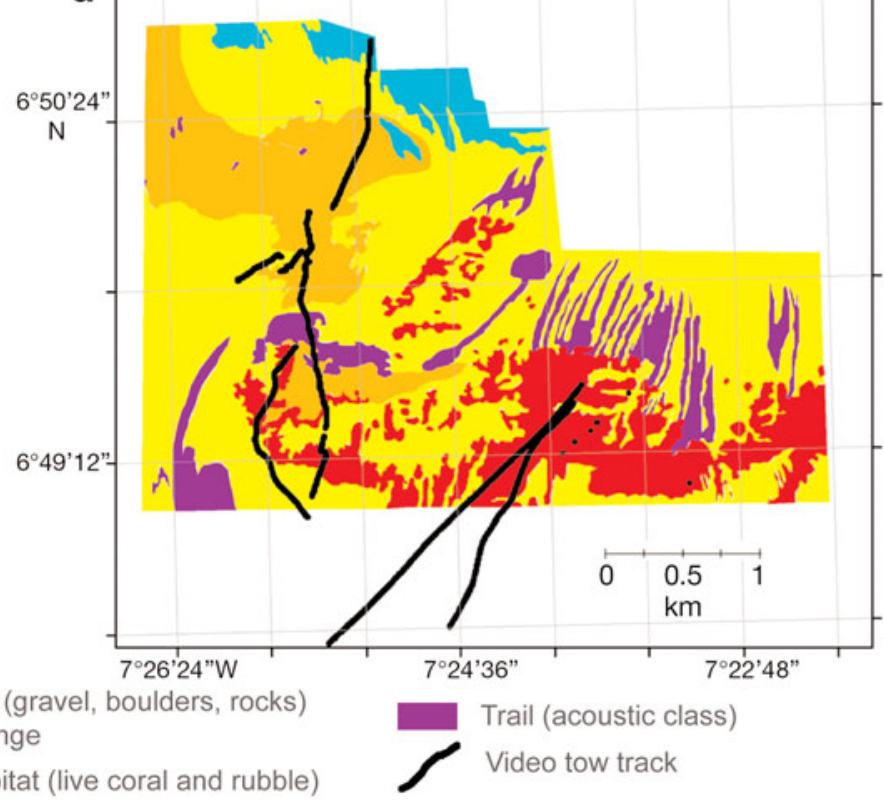

Fig. 2. Distribution of reef habitat across the Mingulay reef complex. (a) Three-dimensional multibeam bathymetry showing where Lophelia pertusa reef habitat has been identified (30 kHz multibeam echosounder (MBES), plotted with $8 \times$ vertical exaggeration). (b) Plan view of multibeam bathymetry from Mingulay Area 1 showing distinctive reef mounds (200 kHz MBES). (c) Backscatter from Mingulay Area 1 shows both reef mounds and trails extending downstream. Horizontal stripes are processing artefacts. (d) Habitat map from Mingulay Area 1 showing broad habitat types and video tow tracks. Panels (b-d) adapted from Roberts et al. (2005)

that would have cut through existing sedimentary strata. Mingulay Areas 5 North and 5 South are also thought to have developed on igneous intrusions since seismic data from these areas show an irregular surface, strong reflectivity and no internal acoustic structure (Roberts et al. 2005).

As well as revealing the mounded seabed bathymetry (Fig. 2b) formed by Lophelia pertusa reefs, the backscatter from the $200 \mathrm{kHz}$ MBES survey revealed distinct 'trail' features extending downstream from the coral mounds (Fig. 2c). These, the reef mounds and other distinct habitats were then mapped using seabed video surveys to identify boundaries between habitat types (Roberts et al. 2005). It was possible to map the following habitats at Mingulay Area 1: bioturbated mud, fine to coarse sediment (many crinoids), coarse substrata (gravel, boulders rocks) with erect sponges, Lophelia pertusa reef habitat (live coral and rubble) and trail features (mapped using acoustic backscatter data, see Fig. 2d).

Side-scan sonar and video surveys of the reef areas at Mingulay have given more information about the different reef areas. Side-scan surveys took place during the RV 'Pelagia' cruise in 2006 using an Ultra Elec- 

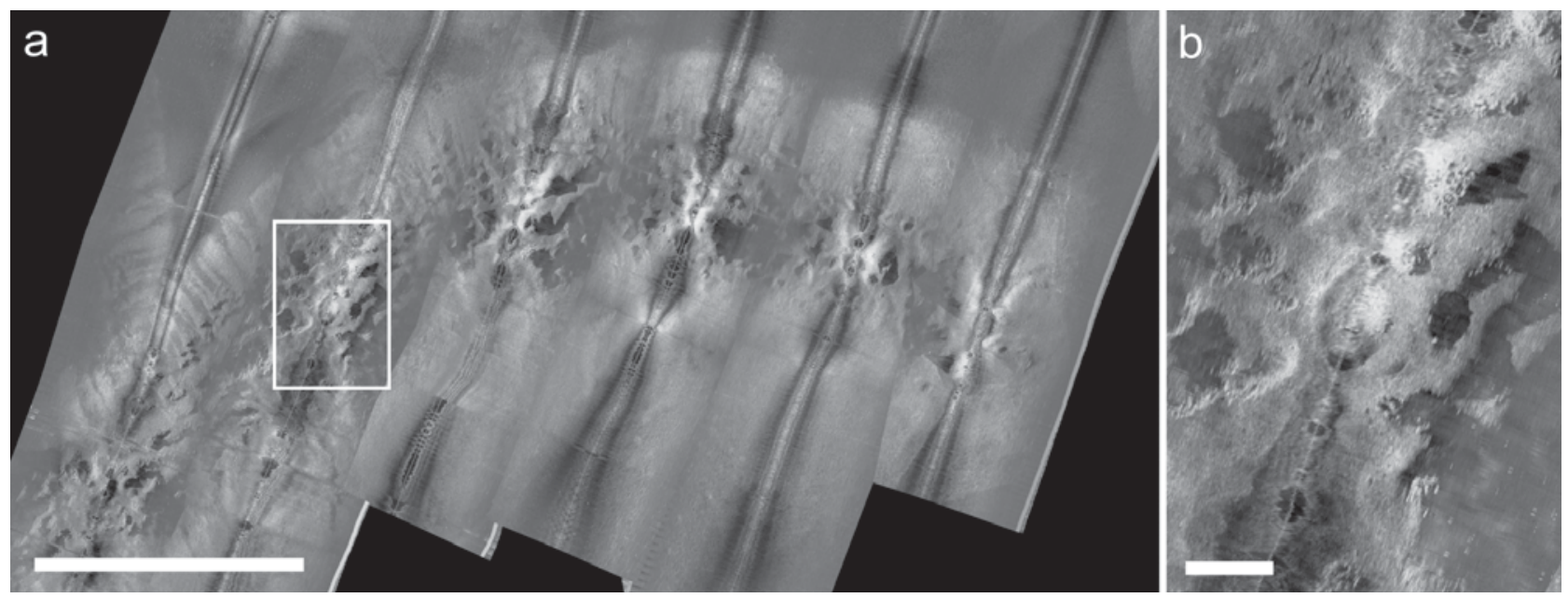

Fig. 3. (a) Side-scan sonar mosaic showing the individual coral reef mounds that form Banana Reef (scale bar $=500 \mathrm{~m}$ ). (b) An enlargement of the area delineated in (a) showing the high backscatter (light) of live coral reefs and the low backscatter (dark) of sediment-covered coral framework compared with the surrounding sediments (scale bar $=50 \mathrm{~m}$ ). Near-vertical striations are processing artefacts (side-scan nadir lines)

tronics Model 3050E Widescan operating at $100 \mathrm{kHz}$ (Maier 2006). Survey lines had a total swath of $400 \mathrm{~m}$ and were spaced at $300 \mathrm{~m}$ giving a $25 \%$ overlap. To improve towfish stability during the surveys, lines were run at 3 to 4 knots from NNE to SSW against the prevailing bottom currents. Using the sonar imagery alongside visual video ground-truthing, it is possible to distinguish live coral patches from dead reef framework. On the side-scan records, live coral patches appear as high backscatter (bright), whereas dead, sediment covered coral framework shows up as low backscatter (dark) compared to the surrounding background sediments (Fig. 3).

Video and side-scan backscatter data have been cross-related from some sites within the reef complex (Green 2007). For example, on the flanks of Mingulay Area 5, live reef is mainly composed of small individual colonies of up to $1 \mathrm{~m}$ diameter (although some larger live coral patches are present) above dead coral framework. On the reef top these colonies appear to have expanded over time to form dense, continuous coral cover. A similar situation was found at Banana Reef, where some reef top patches reach several metres in height and width. Green (2007) produced a $1.3 \mathrm{~km}^{2}$ area habitat map from Mingulay 5 South showing that coral facies, including coral rubble and dead coral framework, accounted for $52 \%$ of this area. However, of the coral facies, just $10 \%$ was classified as live coral framework, illustrating the limited size and patchy distribution of the live coral colonies. Lophelia pertusa coral reef habitat at Mingulay is found between 120 and $190 \mathrm{~m}$ depth.

The side-scan sonar records from Mingulay have also revealed some evidence for trawl marks in the
Mingulay reef complex. In the surveys carried out to date, trawl marks have only been seen in the Four Mounds area (Fig. 4a). We compared the distribution of trawl marks with a proxy of fishing vessel activity derived from vessel monitoring system (VMS) data. Following the approach of Davies et al. (2007), the data from 2007 were filtered to retain vessels steaming at speeds compatible with trawling (1.5 to 4.5 knots). Although data on fishing gear used were not available, it is probable that these vessels were trawling for the burrowing crustacean Nephrops norvegicus, abundant in the deeper muddy habitats of the Scottish west coast. Fig. 4b shows that few vessels were found in the vicinity of the rocky outcrops and coral reefs that characterise the northern portion of the Mingulay reef complex, but more fishing activity was apparent to the south, where the trawl marks within the Four Mounds were found. Despite this, lost fishing nets and cables have also been seen during video surveys of both Banana Reef and Mingulay Area 1, which are further north.

\section{HYDROGRAPHY AND FOOD SUPPLY}

The Mingulay reef complex is found in a topographically complex deep-water channel with a clear connection south to the Scottish continental shelf and Atlantic Ocean. Recent seabed lander and mooring studies have not only confirmed that the Lophelia pertusa reefs are restricted to areas of full salinity Atlantic water (35 psu), but also revealed the hydrographic mechanisms that supply food to the reefs. In other regions, L. pertusa occurrence has been related to a 

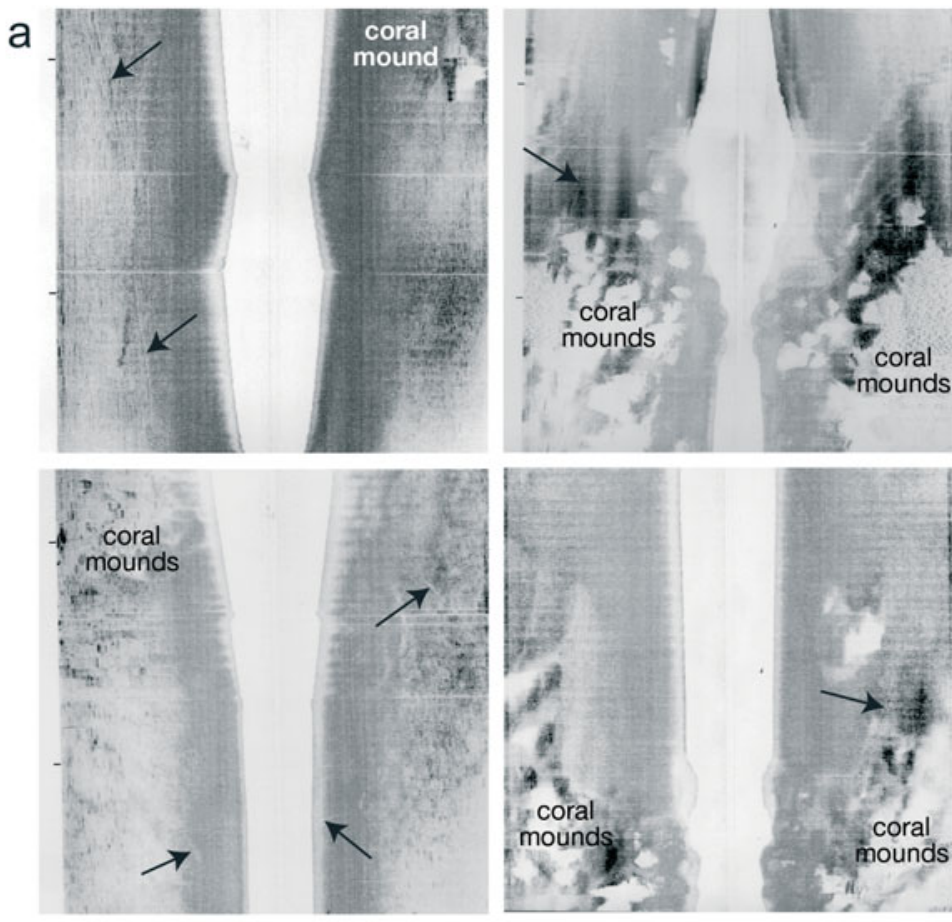

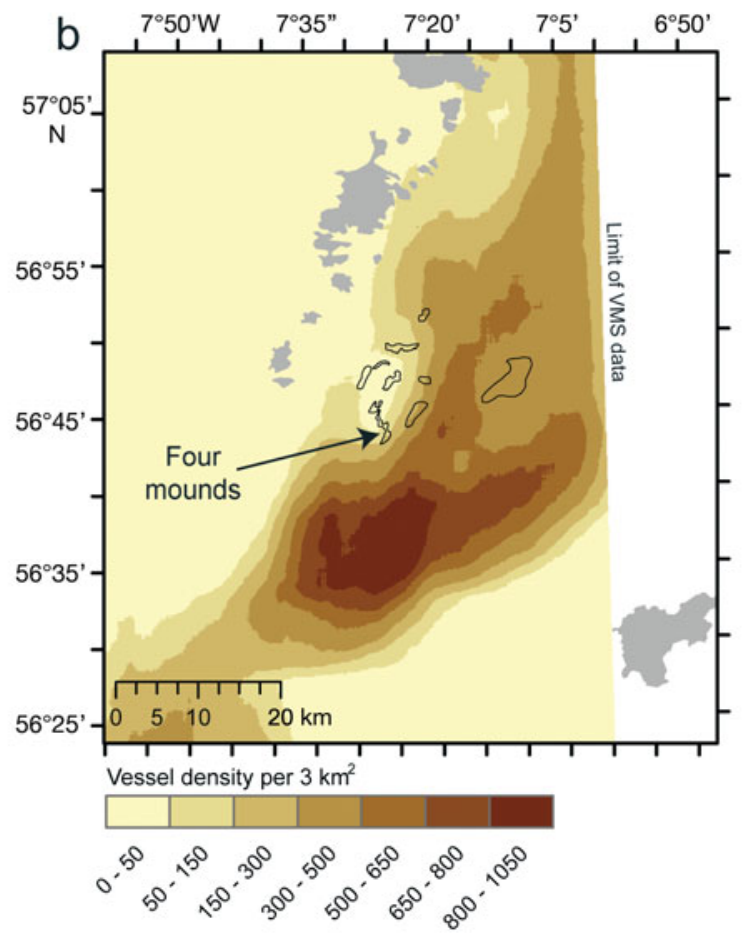

Fig. 4. (a) Examples of uncorrected shipboard side-scan sonar records from Four Mounds showing seabed striations interpreted as trawl marks (black arrows). In order to make these marks more visible, a reverse polarity image is shown with darker high backscatter and lighter low backscatter tones. (b) Estimate of fishing vessel density derived from vessel monitoring system (VMS) data from 2007 in the vicinity of the Mingulay reef complex. Outlines show known areas of coral and rocky reef habitat. The highest density of fishing activity is south of the reef complex and trawl marks have only been detected to date in the Four Mounds area, the most southerly coral site. VMS data copyright Scottish Government

variety of hydrographic factors. Frederiksen et al. (1992) suggested that corals around the Faroe Islands and on Rockall Plateau occurred in areas of critical slope to semidiurnal internal waves. The increased mixing in these areas could help promote primary productivity near shallower Faroe populations and may spread nepheloid layers to deeper-dwelling Rockall populations. Such internal waves have now been recorded transporting fluorescent material to coral carbonate mounds in the southeast Rockall Trough (Duineveld et al. 2007, Mienis et al. 2007). Thiem et al. (2006) used a numerical simulation to show how the accelerated flows along the Norwegian shelf break could enhance food particle flux to the abundant $L$. pertusa reefs found there.

The hydrography of the Mingulay reef complex was first examined in July 2006 using landers and moorings to deploy current meters, fluorometers and optical backscatter sensors. In June 2007, a second cruise followed up on these observations with CTD transects across the reefs and yo-yo CTD sampling at 1 station throughout tidal cycles (Davies et al. 2009). The predominant surface flows between the Outer Hebrides and Scottish mainland are from SSW to NNE, a pattern replicated on the seabed from moorings deployed on crests to the east and west of Mingulay Area 1 (where reefs are best developed on the northern flank of this $\mathrm{E}-\mathrm{W}$ oriented ridge). Near the base of the southern flank of Mingulay Area 1, currents are predominantly SW-NE, reflecting the influence of the local topography in steering current direction. Currents were predominantly tidal and strongest on the crests of the ridge (peak flow $=81 \mathrm{~cm} \mathrm{~s}^{-1}$, mean $=21 \mathrm{~cm} \mathrm{~s}^{-1}$ ) and weaker at the southern base of the ridge (peak flow $=$ $26 \mathrm{~cm} \mathrm{~s}^{-1}$, mean $=12 \mathrm{~cm} \mathrm{~s}^{-1}$ ).

It is these tidal currents impinging on local topography that appear to supply food particles to the reef fauna. As the tide changes from flood to ebb (from northward to southward flow), the waters bathing the reefs warm by $0.75^{\circ} \mathrm{C}$ for approximately $3 \mathrm{~h}$ and the fluorescence recorded doubles (Fig. 5). A similar pattern is seen on the change from ebb to flood but with a smaller $0.2^{\circ} \mathrm{C}$ temperature increase. These phenomena were remarkably consistent and seen in all deployments at Mingulay Area 1 with a 3 month-long mooring from 27 June to 24 September 2007, showing that this warm-water pulse was strongest during spring tides. The CTD transects across Mingulay Area 1 also showed downward movement of surface water 1 to $2 \mathrm{~h}$ after the tide turned, with the largest downwelling 


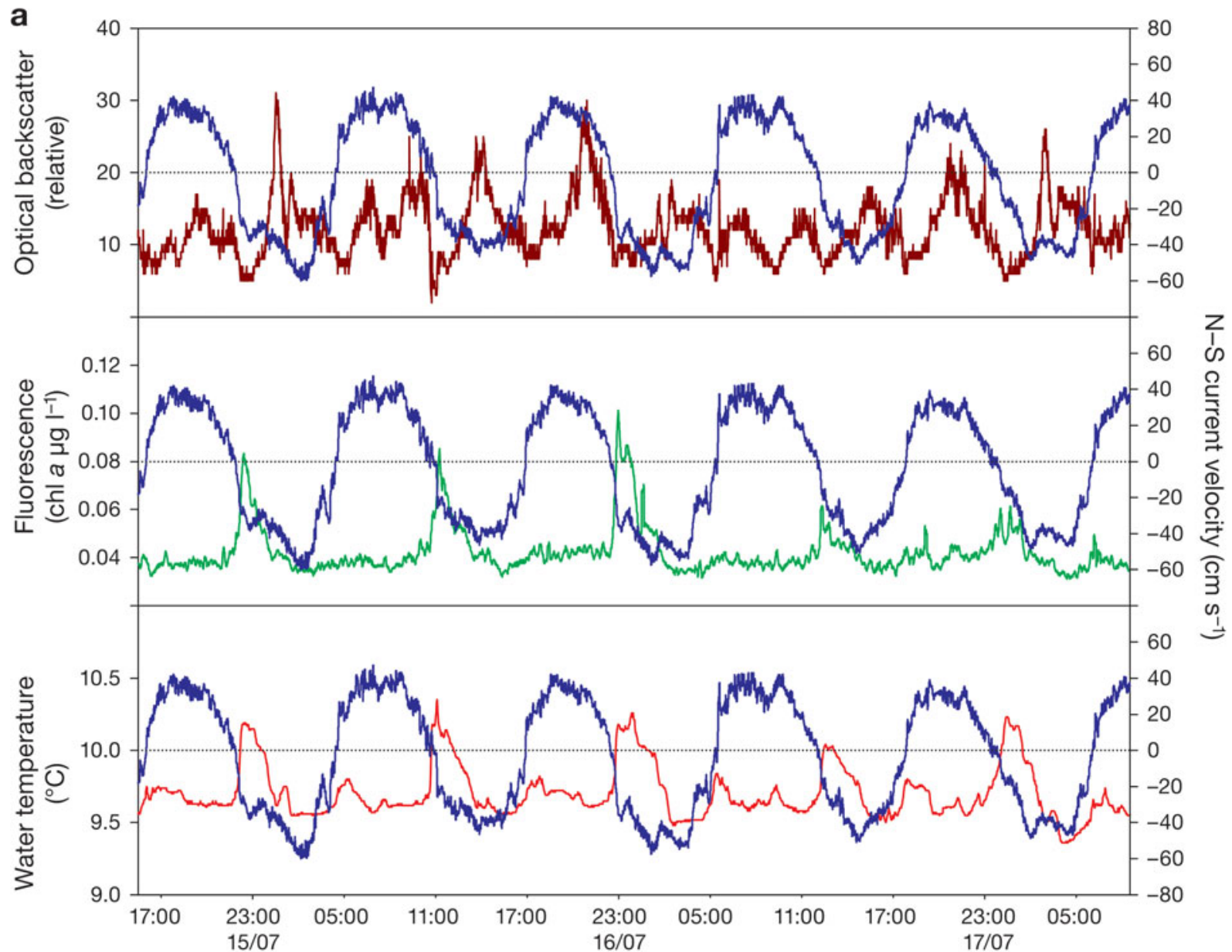

Date $(\mathrm{d} / \mathrm{mo}) /$ Time $(\mathrm{h})$

b

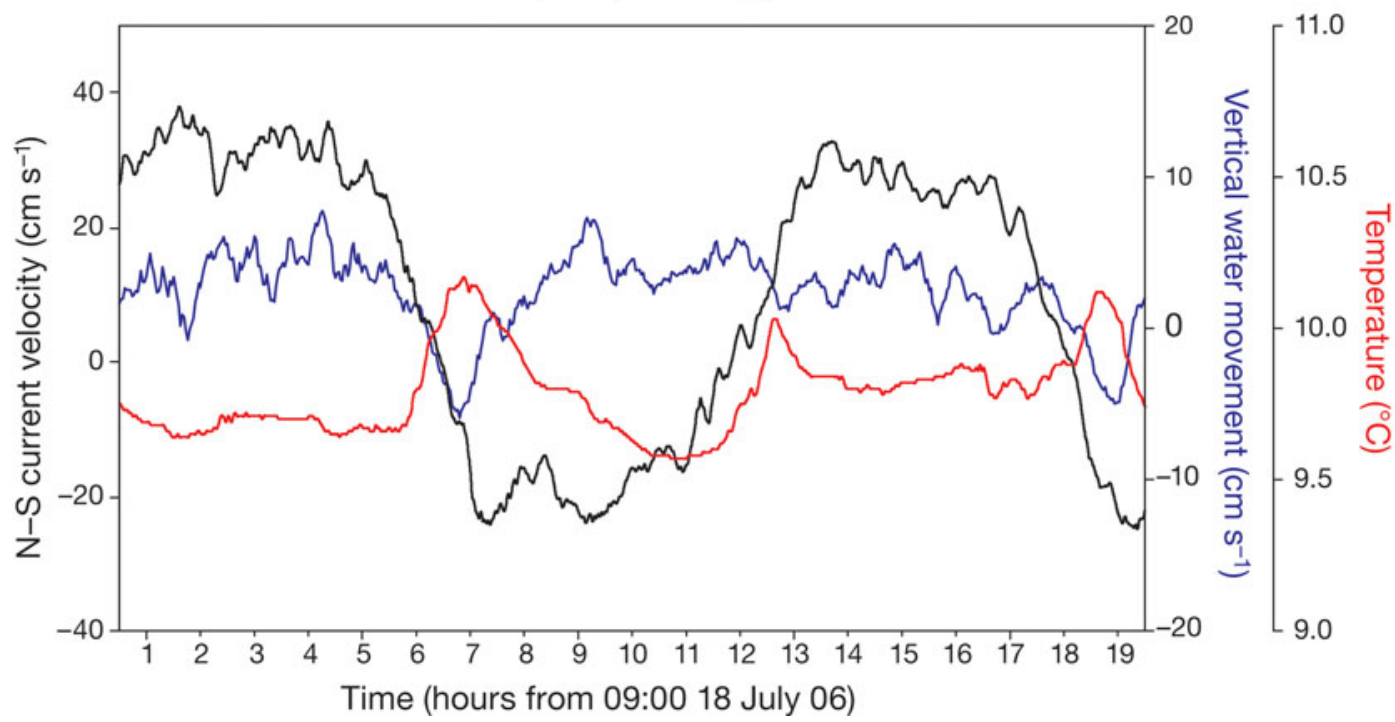

Fig. 5. (a) Relationship between the N-S current velocity (blue line) and turbidity (top; brown line in relative units), fluorescence (middle; green line) and temperature (bottom; red line). Recordings were made using instrumented landers and moorings on the summit of Mingulay Area 1, and 10 min moving averages are plotted. (b) Vertical water movement (blue line), N-S current velocity (black line) and water temperature (red line) recorded by a moored 3-dimensional current meter between 09:00 UTC 18 July 2006 and 04:00 UTC the following morning, also on Mingulay Area 1. The negative vertical water movement at the onset of the ebb tide shows a downward flow associated with the internal 'hydraulic jump'. Adapted from Davies et al. (2009) 
again seen when tide changed from flood to ebb. This downward movement of water at the onset of the ebb was also recorded by moored instruments just above the seabed (Fig. 5b). Near-bed turbidity increased approximately $1 \mathrm{~h}$ after maximum current speeds were recorded. The rapid downwelling motion is interpreted as a 'hydraulic jump' created as an internal wave moved over the $\mathrm{E}-\mathrm{W}$ ridge that forms Mingulay Area 1. In the tidal conditions experienced at the Mingulay reef complex, hydraulic flow over a bank can cause a depression of the downstream density structure; when the tide reverses, this depression propagates across the bank. The net result of this hydraulic jump is that Mingulay Area 1 receives a regular pulse of warmer water, rich in fluorescent material transported to the coral reefs from the surface in less than $1 \mathrm{~h}$. As well as the food delivered from surface waters, the reefs receive a second potential food supply from bottom water advection during peak tidal flows. However, this colder, more turbid water has less fluorescent material and may therefore be of lower food quality (Davies et al. 2009).

\section{CORAL ECOPHYSIOLOGY}

Interestingly, in vitro study of the ecophysiology of Lophelia pertusa implies it may be inherently adapted to take advantage of the periodic food supplied from the warmer downwelling surface waters at Mingulay Area 1. Using closed chamber respirometry, Dodds et al. (2007) examined the respiratory physiology of $L$. pertusa specimens collected from the Mingulay reef complex and maintained in laboratory aquaria. This

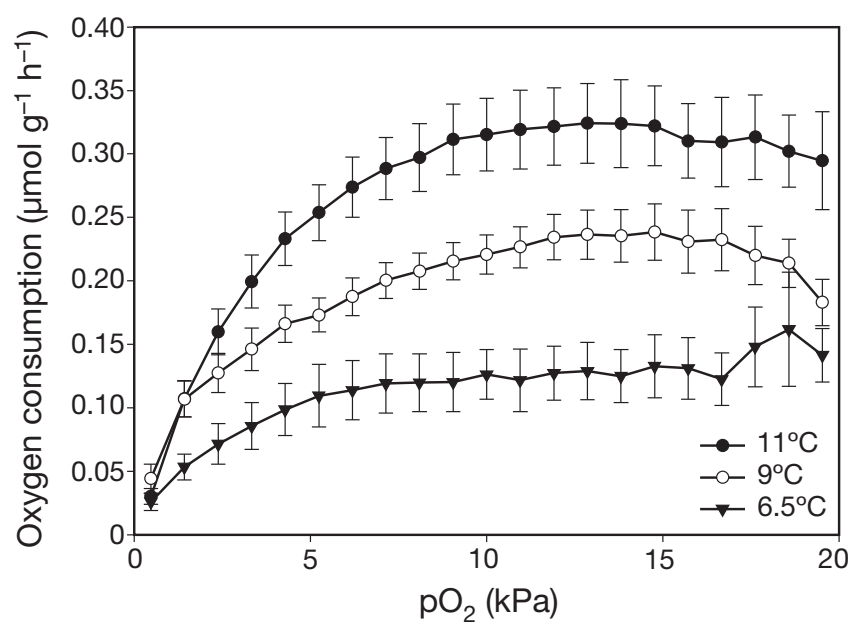

Fig. 6. Lophelia pertusa. Relationship between mean rate of oxygen consumption $( \pm \mathrm{SE})$ of $L$. pertusa and oxygen partial pressure $\left(\mathrm{pO}_{2}\right)$ at 3 different temperatures $\left(6.5,9\right.$ and $\left.11^{\circ} \mathrm{C}\right)$. Data normalised to live coral buoyant weight. Adapted from Dodds et al. (2007) species showed very pronounced changes in metabolic rate over relatively small increases in temperature, illustrated by the doubling in oxygen consumption between corals at 6.5 and $9^{\circ} \mathrm{C}$ and again between corals at 9 and $11^{\circ} \mathrm{C}$ (Fig. 6), all temperatures within the seasonal variation found in the field. Such marked temperature effects produce high $Q_{10}$ values (the factor by which an animal's respiration rate would increase if it were subjected to a $10^{\circ} \mathrm{C}$ temperature increase) and indicate that $L$. pertusa will need substantially greater food supply in warmer water temperatures. Thus it seems that the warmer downwelled water, transporting apparently fresh surface material rapidly to the coral reefs will not only elevate the corals' metabolic rate but also provide increased food input.

The nature of the food particles taken by Lophelia pertusa has also been the subject of recent study at several sites. As with any deep-water species, direct feeding observations are rare and limited to occasional submersible observations of corals taking live calanoid copepods in the field (Freiwald 2002) and notes that corals in aquaria can take both live and dead food materials (Mortensen 2001, Roberts \& Anderson 2002). Indirect diet studies based on $\delta^{15} \mathrm{~N}$ trophic status assessments suggest $L$. pertusa from coral carbonate mounds on Rockall Bank, northeast Atlantic, occupies a similar trophic level to obligate filter-feeding tunicates and bivalve molluscs (Duineveld et al. 2007). On the other hand, Kiriakoulakis et al. (2005) found that $L$. pertusa from a variety of northeast Atlantic sites were enriched in 2 monounsaturated fatty acids only known to be synthesised by calanoid copepods, implying a more carnivorous diet.

Lipid biomarkers in Lophelia pertusa from the Mingulay reef complex have been examined by Dodds et al. (2009, this Theme Section). Their study found that tissue from $L$. pertusa is relatively lipid-rich, containing 5 to $12 \%$ lipid by dry weight, comparable with studies of temperate sea anemones that have 10 to $13 \%$ lipid (Harland et al. 1992), and that L. pertusa samples from Mingulay were more lipid-rich than others from deeper, offshore Atlantic bank and seamount sites. The lipids present were dominated by wax esters, probably reflecting a diet rich in herbivorous calanoid copepods that, at high latitudes, lay down their lipid reserves as wax esters. Mirroring the findings of Kiriakoulakis et al. (2005), Dodds et al. (2009) also reported monosaturated fatty acids $\mathrm{C}_{20: 1}$ and $\mathrm{C}_{22: 1}$, both derived from calanoid copepods, and a lower proportion of phytoplankton-derived polyunsaturated fatty acids. On balance, these lipid biomarkers indicate that $L$. pertusa at Mingulay feeds predominantly on herbivorous calanoid copepods, but at deeper offshore bank and seamount settings carnivorous or omnivo- 
rous non-calanoid copepods become more important prey items.

The differences in copepod prey between the shallow Mingulay corals and those from deeper offshore banks and seamounts, combined with evidence of their trophic status alongside other suspension-feeders, suggests that Lophelia pertusa is rather adaptable in the food items it can take. Thus L. pertusa could feed both on local copepod populations and fresh algal material of the sort regularly transported to the shallow Mingulay Area 1 reefs on the turn of the tide. Further studies including laboratory feeding trials are needed to investigate feeding preferences and see how adaptable this species may be to shifts in food input that might be predicted in a gradually warming (Barnett et al. 2005) and acidifying (Turley et al. 2007) future ocean.

\section{SPATIAL PATTERNS IN BIODIVERSITY}

Deep-water Lophelia pertusa reefs provide a complex spatial and temporal mosaic of habitats ranging from the relatively species-poor stands of live reef framework to dead coral framework colonised by other suspension feeders, sediment-filled reef, coral rubble and background seabed facies (Fig. 7a). Likewise, habitat heterogeneity on the Mingulay reef complex (Fig. $7 b$ ) is reflected in the patterns of biodiversity found with the associated biological communities.

A checklist of the fauna from the Mingulay reef complex lists 358 taxa in total with 215 identified to species level (Supplement 1, available as MEPS Supplementary Material at: www.int-res.com/articles/suppl/ m397p139_app.pdf). Most of the species are typical of the temperate inshore British fauna; however, some of the sponge species found have typically Lusitanian distributions, even penetrating into the Mediterranean, and thus exhibit far greater ranges than previously thought. Detailed study of the sponge fauna revealed 100 species, including one, Cliona caledoniae, which was new to science (van Soest \& Beglinger 2009). In addition, there are no hexactinellid (glass) sponges, few calcareous sponges and several shallow sublittoral sponge species on the Mingulay reefs. These observations point to interesting future questions about how the hydrography and ocean chemistry around Mingulay control the distribution of such a rich sponge fauna.
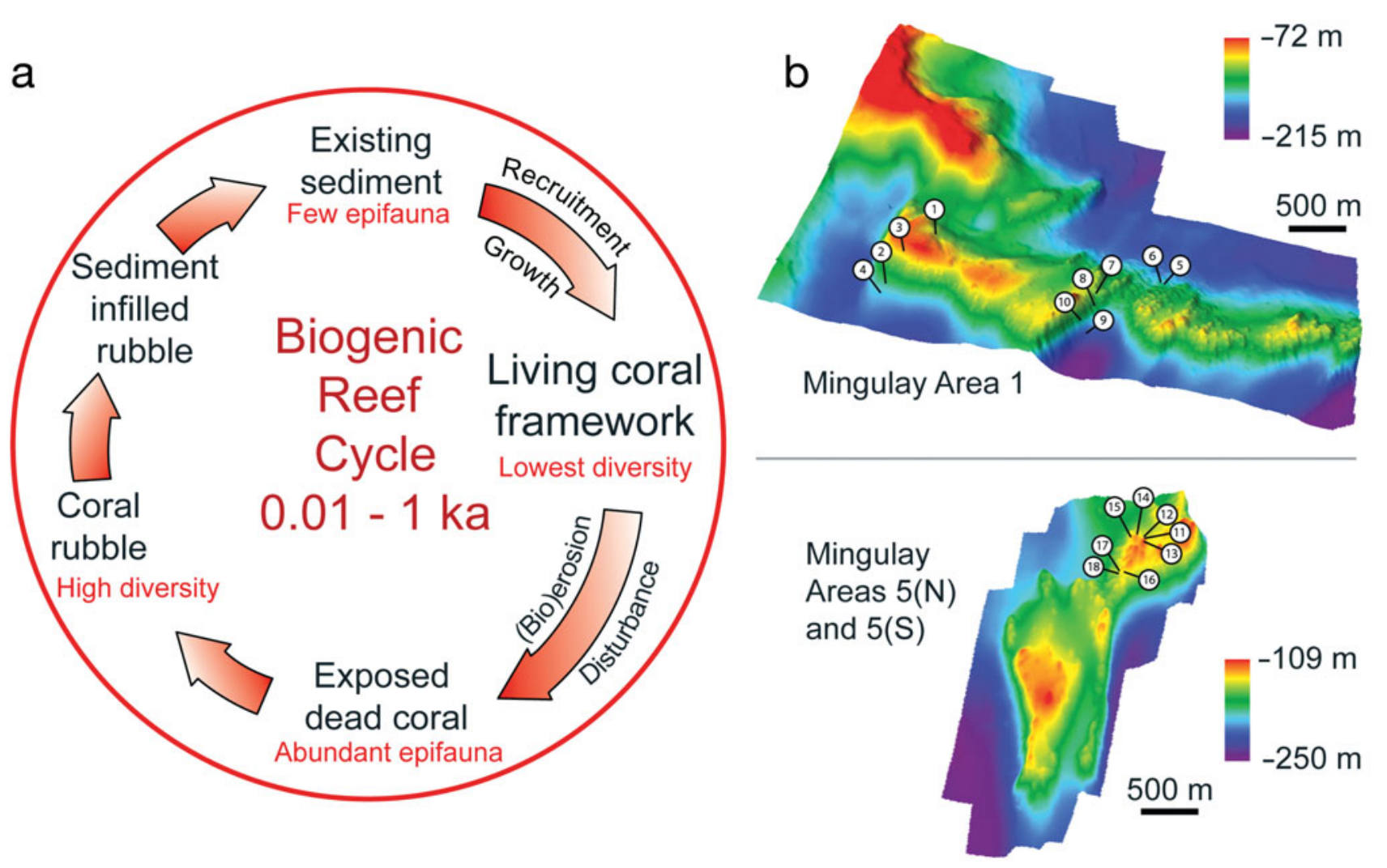

Fig. 7. (a) Schematic showing cold-water coral reef habitat development and likely species diversity change between habitats. (b) Colour-coded 3-dimensional bathymetry (plotted with $3.5 \times$ vertical exaggeration) showing location of Day grab samples on Mingulay Areas 1 and 5 North (N). (a) Adapted from Roberts et al. (2006); (b) adapted from Henry et al. (in press) 
Overall, biodiversity patterns at Mingulay, and likely at other cold-water coral reefs, are significantly spatially structured: that is, both $\alpha$ and $\beta$ diversity vary across spatial gradients on the reef complex. This is most noticeable at Mingulay when one considers the changes in fauna from west to east. Using multibeam bathymetry data to estimate several seabed terrain variables, ground-truthed data were integrated with these remotely-sensed data to generate a set of variables that could explain patterns in macrofaunal biodiversity (Henry et al. in press). Alpha diversity was significantly correlated to longitude, being highest in the westernmost reaches of the reef complex where rock and coral rubble macrohabitats predominated. Combinations of gradients in latitude, longitude, rugosity, northerly aspect, easterly aspect, bathymetric position index (a measure of sample site elevation or depression), macrohabitat and species richness explained $68 \%$ of the spatial variation in community composition ( $\beta$ diversity); however, community dissimilarity (variation in $\beta$ diversity) increased solely with longitudinal distance between sites. Thus, although spatial variation in $\beta$ diversity can be explained by a quasi-neutral factor (i.e. the longitudinal distance between sites) that could suggest limited dispersal between more distant sites, underlying niche mechanisms create $\beta$ diversity by partitioning species across environmental gradients that are spatially structured on the reef complex (Henry et al. in press). Furthermore, hydrographical variables (turbidity, current speeds) are spatially structured from west to east on the reef complex (Davies et al. 2009) and will also undoubtedly play a role in explaining the spatial dependence of associated biological communities.

\section{TEMPORAL HISTORY OF REEF DEVELOPMENT}

At the time of writing, work to understand the geological history of reef development at Mingulay had just begun and only preliminary information can be summarised here. Reservoir-corrected accelerator mass spectrometry dates for coral rubble gathered from the seafloor in 2003 were $3540 \pm 56$ (SD) and 3864 \pm 33 yr BP (year 1950) (Roberts et al. 2005). It is highly likely that coral material within the individual reef mounds at Mingulay is considerably older, potentially extending back to the early post-glacial (10 $000 \mathrm{yr} \mathrm{BP})$, as shown by dating studies of Lophelia pertusa reefs on the Norwegian continental shelf (Mikkelsen et al. 1982, Hovland et al. 1998). The history of coral occurrence at Mingulay is the subject of ongoing research using a series of cores taken through the reef mounds in 2007 that revealed at least $5.4 \mathrm{~m}$ of deposited coral

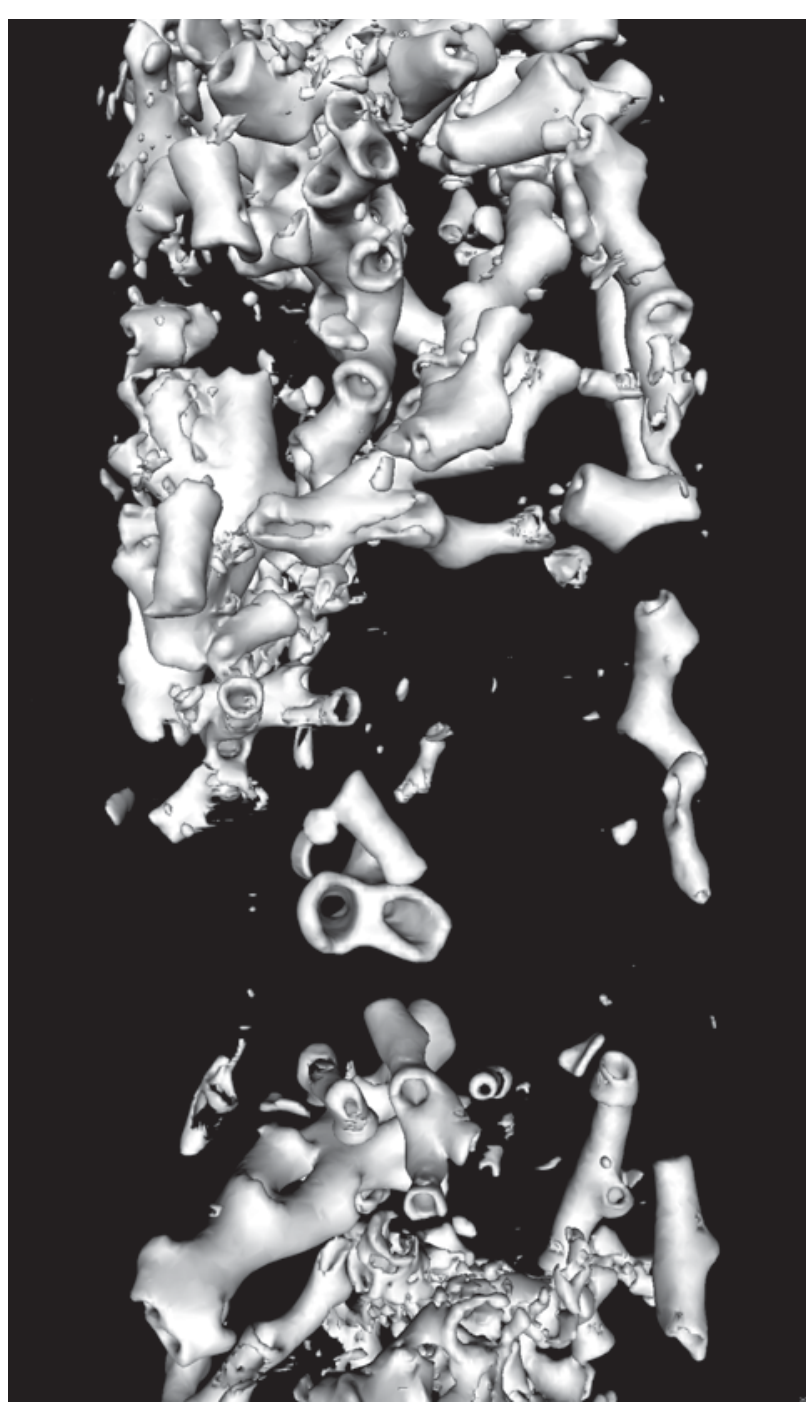

Fig. 8. Lophelia pertusa. A computed tomography (CT) scan of a vibro-core from the Mingulay reef complex showing abundant fragments of $L$. pertusa skeleton. The core is $85 \mathrm{~mm}$ in diameter

debris (Stewart \& Gatliff 2008). An example of the abundant coral material in one of these cores is illustrated in Fig. 8.

The cores form a dense mesh of coral rubble interspersed with fine grey muds. Preliminary results from computed tomography scanning of intact cores (Sinclair et al. 2008) show the following: (1) coral clasts are not distributed evenly and there are conspicuous horizons where no coral rubble is present; (2) coral clasts vary significantly in their level of preservation-in some places coral fragments appear whole and pristine, while in others they are heavily microbored and/or fragmented; (3) degraded clasts are not distributed randomly, but can be found at higher abundance in distinct layers within the core; and (4) there is no 
apparent relationship between degree of degradation and position within the core-pristine material can be found at the very bottom of the cores, while heavily microbored material can be found near the top. The presence of distinct layers within the cores suggests that this coral mound is not being reworked, as this would destroy such internal stratigraphy. Once cores are opened we will investigate whether elevated deposition of muds and/or clast dissolution (e.g. Foubert et al. 2007) are responsible for the gaps and the horizons with more biodegraded clasts.

\section{CONCLUSIONS}

Corals and the habitats they form fall at a natural confluence of biology, geology and hydrography. Understanding any one aspect of cold-water coral ecology, be it the biodiversity they support or the trophic status of the community, may be futile without supporting knowledge of the physical geological structure surrounding the habitats and the nature of the hydrographic environment in which they have developed. The present study summarised our current understanding of one such cold-water coral habitat to the west of Scotland, a relatively shallow example of a scleractinian reef framework formed by Lophelia pertusa, the most globally widespread reef-forming coldwater coral. Initial information on coral occurrence east of Mingulay in the Sea of the Hebrides came first from fishing records and baseline geological mapping. By refining the geological mapping and using both MBES and higher resolution side-scan sonar it has been possible to identify, map and even estimate likely coverage of live coral within the Mingulay reef complex. Seabed morphology allows us to interpret the structures on which cold-water coral reefs have developed, and recent seabed drilling confirms that one of the large reefs, Mingulay Area 1, has developed on the flanks of an igneous dolerite sill within Lower Jurassic sedimentary rocks.

The coral reefs at Mingulay are tightly coupled to surface primary productivity with those at Mingulay Area 1 bathed twice a day by warm, fluorescent surface waters transported rapidly to the seabed by a hydraulic jump associated with the movement of strong tidal currents across the dolerite sill. While interesting as a field observation, the significance of this possible food supply mechanism is brought into focus by understanding the respiratory physiology of Lophelia pertusa and examining proxies for its food sources. This study of coral respiration in the laboratory suggests that oxygen consumption by L. pertusa exposed to the warm downwelled water will increase by 30 to $50 \%$ (Dodds et al. 2007). It is interesting to speculate that the apparent increase in food supply from the surface will compensate for this increase in metabolic rate and that $L$. pertusa is adapted to take advantage of these periods of greater food availability. For example, recent analysis of polyp behaviour from corals deployed on benthic landers at Mingulay implies increased feeding activity associated with warm, downwelling water (A. J. Davies et al. unpubl. data). More in situ studies assessing both coral behaviour and physiological responses to environmental cues are needed. The lipid biomarkers found in L. pertusa from Mingulay implied a diet consisting predominantly of herbivorous calanoid copepods. This again reinforces the short food chain of the shallow Mingulay corals compared with samples collected from deeper offshore Atlantic banks and seamounts, where L. pertusa may be more reliant on carnivorous or omnivorous non-calanoid copepods and, in some settings, intermediate nepheloid layers.

As we learn more about Lophelia pertusa and the habitats it forms, it seems the wide occurrence of this species may relate to its cosmopolitan feeding abilities. There is a clear need for controlled laboratory studies of feeding preference and growth to further examine these questions. Such studies need to be grounded in field observations of the temporal variability in environmental variables and food input. Long-term oceanographic landers, moorings and seasonal water column and coral sampling are all needed to study these issues and track any warming or acidification trends in the waters where cold-water coral reefs are found. Such environmental information, combined with physical data from multibeam surveys, also provides essential context to interpret spatial patterns in biodiversity. Ongoing work to understand the historical record of coral growth at Mingulay will help better interpretation of biogeographic patterns in the rich fauna it now supports.

Despite its wide occurrence and evidence that Lophelia pertusa may be adapted to feed on a variety of foods, it remains clear that these habitats are threatened by bottom trawling. Acoustic evidence for trawl marks and visual records of anthropogenic waste at Mingulay both illustrate this. While properly monitored marine protected areas offer means of preventing damage from bottom trawling, the effects of ocean warming and acidification will transcend reserve boundaries around the world. As with the need for integrated, interdisciplinary study of coldwater coral habitats, there has never been a greater need for truly integrated thinking-management should involve not just closing areas to fishing, but a move toward universal conservation measures with climate change control forming a central guiding principle. 
Acknowledgements. Initial mapping of the Mingulay reef complex took place through the Mapping Inshore Coral Habitats (MINCH) project between the Scottish Association for Marine Science (SAMS), British Geological Survey (BGS), TOPAZ Environmental \& Marine and the Department of Agriculture and Rural Development (Northern Ireland). Funding for the multibeam sonar used in the MINCH project was provided by the Scottish Executive and Scottish Natural Heritage. Subsequent work has been supported by the European Sixth Framework Programme projects 'European Cold-water Coral Ecosystems' (ECCRE contract MIF1-CT-2004-002469 to L.A.H. and J.M.R.) and 'Trans-Atlantic Coral Ecosystem Studies' (TRACES contract MOIF-CT-2006-040018 to J.M.R.) under the programmes 'Structuring the European Research Area' and 'Hotspot Ecosystem Research on the Margins of European Seas' (HERMES contract GOCE-CT-2005-511234 to J.M.R. \& G.C.A.D.) under the programme 'Sustainable Development, Global Change and Ecosystems'. Ecophysiological and lipid biomarker work was funded by the UK Natural Environment Research Council (grant NER/S/A/2003/ 11898 to J.M.R.). We are very grateful to the captains and crews of RV 'Calanus', MY 'Esperanza', RV 'Lough Foyle' and RV 'Pelagia' for assistance at sea. The 2006 RV 'Pelagia' Cruise (64PE250) was funded by the Dutch National Science Foundation BIOSYS project (to C.M.). Vessel monitoring system data are courtesy of the Scottish Fisheries Protection Agency. We acknowledge T. Beck, J. Duncan, the late J. Gage, C. Goodwin, R. Harvey, D. Hughes, P. Lamont, B. Picton and L. Robb for assistance with faunal identification. D.L. and S.L.G. publish with permission of the Executive Director, British Geological Survey (Natural Environment Research Council).

\section{LITERATURE CITED}

Adkins JF, Cheng H, Boyle EA, Druffel ERM, Edwards RL (1998) Deep-sea coral evidence for rapid change in ventilation history of the deep north Atlantic 15,400 years ago. Science 280:725-728

Barnett TP, Pierce DW, AchutaRao KM, Gleckler PJ, Santer BD, Gregory JM, Washington WM (2005) Penetration of human-induced warming into the world's oceans. Science 309:284-287

Cairns SD (2007) Deep-water corals: an overview with special reference to diversity and distribution of deep-water scleractinian corals. Bull Mar Sci 81:311-322

Cordes EE, McGinley MP, Podowski EL, Becker EL, LessardPilon S, Viada ST, Fisher CR (2008) Coral communities of the deep Gulf of Mexico. Deep-Sea Res I 55:777-787

Davies AJ, Roberts JM, Hall-Spencer J (2007) Preserving deep-sea natural heritage: emerging issues in offshore conservation and management. Biol Conserv 138: 299-312

Davies AJ, Duineveld G, Lavaleye M, Bergman MJ, van Haren H, Roberts JM (2009) Downwelling and deep-water bottom currents as food supply mechanisms to the coldwater Lophelia pertusa (Scleractinia) at the Mingulay reef complex. Limnol Oceanogr 54:620-629

> Dodds LA, Roberts JM, Taylor AC, Marubini F (2007) Metabolic tolerance of the cold-water coral Lophelia pertusa (Scleractinia) to temperature and dissolved oxygen change. J Exp Mar Biol Ecol 349:205-214

Dodds LA, Black KD, Orr H, Roberts JM (2009) Lipid biomarkers reveal geographical differences in food supply to the cold-water coral Lophelia pertusa (Scleractinia). Mar Ecol Prog Ser 397:113-124
Duineveld GCA, Lavaleye MSS, Berghuis EM (2004) Particle flux and food supply to a seamount cold-water coral community (Galicia Bank, NW Spain). Mar Ecol Prog Ser 277: $13-23$

Duineveld GCA, Lavaleye MSS, Bergman MJN, de Stigter H, Mienis F (2007) Trophic structure of a cold-water coral mound community (Rockall Bank, NE Atlantic) in relation to the near-bottom particle supply and current regime. Bull Mar Sci 81:449-467

Eden RA, Ardus DA, Binns PE, McQuillin R, Wilson JB (1971) Geological investigations with a manned submersible off the west coast of Scotland 1969-1970. Report No. 71/16, Institute of Geological Sciences, London

Fleming J (1846) On the recent Scottish Madrepores, with remarks on the climatic character of the extinct races. Proc R Soc Edinb 2:82-83

Foubert A, Van Rooij D, Blamart D, Henriet JP (2007) X-ray imagery and physical core logging as a proxy of the content of sediment cores in cold-water coral mound provinces: a case study from Porcupine Seabight, SW of Ireland. Int J Earth Sci 96:141-158

Frederiksen R, Jensen A, Westerberg H (1992) The distribution of the scleractinian coral Lophelia pertusa around the Faroe Islands and the relation to internal tidal mixing. Sarsia 77:157-171

Freiwald A (2002) Reef-forming cold-water corals. In: Wefer G, Billett D, Hebbeln D, Jorgensen BB, Schluter M, Van Weering $\mathrm{T}$ (eds) Ocean margin systems. Springer-Verlag, Berlin/Heidelberg/New York, p 365-385

Green SL (2007) A comparison of the habitat structure and ecology at Mingulay reef complex, Outer Hebrides and the Sula Ridge reef complex, Norway. MS thesis, University of Southampton

Griffiths C (2002) Discovery 257. SAMS northern seas programme, 21st September-9th October 2001. Clyde-Clyde, internal cruise report, Scottish Association for Marine Science, Oban

Gunnerus JE (1768) Om nogle Norske coraller. K Norske Vidensk Selsk Skr 4:38-73

> Harland AD, Fixter LM, Davies PS, Anderson RA (1992) Effect of light on the total lipid-content and storage lipids of the symbiotic sea-anemone Anemonia viridis. Mar Biol 112: $253-258$

Henriet J, De Mol B, Pillen S, Vanneste M and others (1998) Gas hydrate crystals may help build reefs. Nature 391: 648-649

> Henry LA, Roberts JM (2007) Biodiversity and ecological composition of macrobenthos on cold-water coral mounds and adjacent off-mound habitat in the bathyal Porcupine Seabight, NE Atlantic. Deep-Sea Res I 54:654-672

Henry LA, Davies AJ, Roberts JM (in press) Beta diversity of cold-water coral reef communities off western Scotland. Coral Reefs

Hovland M (2008) Deep-water coral reefs. Unique biodiversity hotspots. Springer-Praxis, Chichester

Hovland M, Risk M (2003) Do Norwegian deep-water coral reefs rely on seeping fluids? Mar Geol 198:83-96

Hovland M, Thomsen E (1997) Cold-water corals-are they hydrocarbon seep related? Mar Geol 137:159-164

Hovland M, Mortensen P, Brattegard T, Strass P, Rokoengen K (1998) Ahermatypic coral banks off Mid-Norway: evidence for a link with seepage of light hydrocarbons. Palaios 13:189-200

> Jonsson LG, Nilsson PG, Floruta F, Lundälv T (2004) Distributional patterns of macro- and megafauna associated with a reef of the cold-water coral Lophelia pertusa on the Swedish west coast. Mar Ecol Prog Ser 284:163-171 
Kiriakoulakis K, Fisher E, Wolff GA, Freiwald A, Grehan A, Roberts JM (2005) Lipids and nitrogen isotopes of two deep-water corals from the north-east Atlantic: initial results and implications for their nutrition. In: Freiwald A, Roberts JM (eds) Cold-water corals and ecosystems. Springer, Berlin/Heidelberg/New York, p 715-729

Kiriakoulakis K, Freiwald A, Fisher E, Wolff GA (2007) Organic matter quality and supply to deep-water coral/mound systems of the NW European continental margin. Int J Earth Sci 96:159-170

Maier C (2006) Biology and ecosystem functioning of cold water coral bioherms at Mingulay (Hebrides), NE Atlantic. Cruise Report, BIOSYS 2006 Cruise 64PE250 on R/V Pelagia, Oban-Oban, 7-23 July 2006. Royal Netherlands Institute for Sea Research, Texel

Mangini A, Lomitschka M, Eichstädter R, Frank N, Vogler S (1998) Coral provides way to age deep water. Nature 392: 347-348

Mienis F, de Stigter HC, White M, Duineveld G, De Haas $H_{\text {, }}$ van Weering TCE (2007) Hydrodynamic controls on coldwater coral growth and carbonate-mound development at the SW and SE Rockall Trough Margin, NE Atlantic Ocean. Deep-Sea Res I 54:1655-1674

Mikkelsen N, Erlenkeuser H, Killingley JS, Berger WH (1982) Norwegian corals: radiocarbon and stable isotopes in Lophelia pertusa. Boreas 11:163-171

Mortensen PB (2001) Aquarium observations on the deepwater coral Lophelia pertusa (L., 1758) (Scleractinia) and selected associated invertebrates. Ophelia 54:83-104

Mortensen PB, Fosså JH (2006) Species diversity and spatial distribution of invertebrates on deep-water Lophelia pertsua in Norway. Proc 10th Int Coral Reef Symp, Okinawa, p 1849-1868

Pontoppidan E (1755) The natural history of Norway, Vol A. Linde, London

Roark EB, Guilderson TP, Dunbar RB, Ingram BL (2006) Radiocarbon-based ages and growth rates of Hawaiian deep-sea corals. Mar Ecol Prog Ser 327:1-14

Roberts JM, Anderson RM (2002) A new laboratory method for monitoring deep-water coral polyp behaviour. Hydrobiologia 471:143-148

Roberts J, Brown C, Long D, Wilson C, Bates C, Mitchell A, Service M (2004) Mapping INshore Coral Habitats, the MINCH project. Scottish Association for Marine Science, Oban

Roberts JM, Brown CJ, Long D, Bates CR (2005) Acoustic mapping using a multibeam echosounder reveals coldwater coral reefs and surrounding habitats. Coral Reefs $24: 654-669$

Submitted: February 4, 2009; Accepted: May 15, 2009
Roberts JM, Wheeler AJ, Freiwald A (2006) Reefs of the deep: the biology and geology of cold-water coral ecosystems. Science 312:543-547

> Roberts JM, Henry LA, Long D, Hartley JP (2008) Cold-water coral reef frameworks, megafaunal communities and evidence for coral carbonate mounds on the Hatton Bank, north east Atlantic. Facies 54:297-316

Roberts JM, Wheeler AJ, Freiwald A, Cairns SD (2009) Coldwater corals: the biology and geology of deep-sea coral habitats. Cambridge University Press, Cambridge

Rüggeberg A, Fietzke J, Liebetrau V, Eisenhauer A, Dullo WC, Freiwald A (2008) Stable strontium isotopes $\left(\delta^{88 / 86} \mathrm{Sr}\right)$ in cold-water corals - a new proxy for reconstruction of intermediate ocean water temperatures. Earth Planet Sci Lett 269:570-575

Sinclair D, Douarin M, Long D, Roberts JM, Elliott M (2008) $\mathrm{X}$-ray vision - a first look inside the Mingulay Lophelia reef. In: Neil HL, Tracey D (eds) 4th Int Symp Deep-Sea Corals, Wellington (Abstract), p 192

Smith JE, Schwarcz HP, Risk MJ, McConnaughey TA, Keller N (2000) Paleotemperatures from deep-sea corals: overcoming 'vital effects'. Palaios 15:25-32

Stewart HA, Gatliff RW (2008) Preliminary geological results of sea-bed sampling in the Hebrides area from the RRS James Cook in 2007. British Geological Survey Internal Report IR/08/004, Edinburgh

> Thiem Ø, Ravagnan E, Fosså JH, Bernsten J (2006) Food supply mechanisms for cold-water corals along a continental shelf. J Mar Syst 60:207-219

Turley C, Roberts JM, Guinotte JJ (2007) Corals in deep water: Will the unseen hand of ocean acidification destroy cold water ecosystems? Coral Reefs 26:445-448

van Soest RWM, Beglinger EJ (2009) New bioeroding sponges from Mingulay coldwater reefs, north-west Scotland. J Mar Biol Assoc UK 89:329-335

van Soest RWM, Cleary DFR, de Kluijver MJ, Lavaleye MSS, Maier C, van Duyl FC (2007) Sponge diversity and community composition in Irish bathyal coral reefs. Contrib Zool 76:121-142

Weber JN, Woodhead PM (1972) Temperature dependence of oxygen-18 concentration in reef coral carbonates. J Geophys Res 77:463-473

White M, Mohn C, de Stigter H, Mottram G (2005) Deepwater coral development as a function of hydrodynamics and surface productivity around the submarine banks of the Rockall Trough, NE Atlantic. In: Freiwald A, Roberts JM (eds) Cold-water corals and ecosystems. Springer, Berlin/Heidelberg/New York, p 503-514

Proofs received from author(s): September 11, 2009 